\title{
Severe Preeclampsia
}

National Cancer Institute

\section{Source}

National Cancer Institute. Severe Preeclampsia. NCI Thesaurus. Code C112843.

Preeclampsia with a systolic blood pressure of $160 \mathrm{mmHg}$ or higher, or a diastolic blood pressure of $110 \mathrm{mmHg}$ or higher on two occasions at least 4 hours apart while on bedrest. It is associated with thrombocytopenia (platelets less than 100,000 per microliter), impaired liver function (twice normal elevation of hepatic transaminases; severe, persistent right upper quadrant or epigastric pain), progressive renal insufficiency (serum creatinine greater than $1.1 \mathrm{mg} / \mathrm{dL}$ or doubling of baseline in the absence of other renal disease), pulmonary edema, or new-onset cerebral or visual disturbances. 